\title{
Loss of histone H2AX increases sensitivity of immortalized mouse fibroblasts to the topoisomerase II inhibitor etoposide
}

\author{
FRANCESCA DONÀ ${ }^{1}$, ENNIO PROSPERI ${ }^{1}$, MONICA SAVIO $^{2}$, TANIA COPPA $^{2}$, \\ A. IVANA SCOVASSI ${ }^{1}$ and CHIARA MONDELLO ${ }^{1}$ \\ ${ }^{1}$ Istituto di Genetica Molecolare CNR, Via Abbiategrasso 207; ${ }^{2}$ Dipartimento di Medicina Sperimentale, \\ Patologia Generale, Università di Pavia, Piazza Botta, I-27100 Pavia, Italy
}

Received March 27, 2008; Accepted May 22, 2008

DOI: 10.3892/ijo_00000047

\begin{abstract}
In mammalian cells, the $\mathrm{H} 2 \mathrm{AX}$ histone is rapidly phosphorylated upon the induction of DNA double strand breaks and promotes their repair, which is required for preserving genomic integrity. Etoposide is an inhibitor of DNA topoisomerase II, which causes DNA breaks and induces H2AX phosphorylation. To elucidate whether H2AX may affect cellular sensitivity to etoposide, we studied the response to this agent in immortalized embryonic fibroblasts derived from $H 2 A X$ knockout mice. Clonogenic assays in cells treated with the drug revealed a greater sensitivity of $\mathrm{H} 2 \mathrm{AX}$ null cells compared to wild-type cells, possibly due to the persistence of a higher number of DNA breaks, as detected with the comet assay. In both cell lines, etoposide induced micronuclei formation and nuclear fragmentation; however, in H2AX deficient cells nuclear fragmentation was observed at a lower drug concentration. Flow cytometric analysis showed that etoposide induced a $\mathrm{G}_{2} / \mathrm{M}$ cell cycle arrest in both cell lines, which occurred at lower drug concentrations in $\mathrm{H} 2 \mathrm{AX}$ deficient cells. $G_{2} / M$ arrest was paralleled by an accumulation of cyclin A and cyclin B1, suggesting that treated cells are not able to complete cell cycle correctly and undergo cell death. Taken together, our observations suggest that H2AX takes part to the cellular response to etoposide and confirm its role in the maintenance of genome stability.
\end{abstract}

\section{Introduction}

One of the earliest events upon double strand break (DSB) induction is serine phosphorylation of the carboxy-terminal tail of the histone variant $\mathrm{H} 2 \mathrm{AX}$, to form $\gamma \mathrm{H} 2 \mathrm{AX}$ (1-3). In a few seconds, H2AX phosphorylation spreads along the chromatin surrounding a DSB, covering from thousands to

Correspondence to: Dr Chiara Mondello, Istituto di Genetica Molecolare CNR, Via Abbiategrasso 207, I-27100 Pavia, Italy E-mail: mondello@igm.cnr.it

Key words: H2AX, etoposide, comet assay, micronuclei, cell cycle, mitotic death a million of bases. This chromatin modification results in a platform for a rapid and ordered assembly of check-point and DNA repair factors, which form multi-protein complexes around a DSB (4). H2AX involvement in DSB response was clearly demonstrated by the observation that mice in which $H 2 A X$ had been ablated by homologous recombination are hypersensitive to ionizing radiation, similarly to deficient $H 2 A X$ mouse embryonic stem cells $(5,6)$. Absence of $\mathrm{H} 2 \mathrm{AX}$ leads to a reduced efficiency of DSB repair upon irradiation and to an impairment in the activation of the DNA damage induced $\mathrm{G}_{2} / \mathrm{M}$ check-point after low $\gamma$-ray doses (5-7). In addition, H2AX deficient cells show high levels of spontaneous chromosomal instability (5). Evidence has also been reported that $\mathrm{H} 2 \mathrm{AX}$ plays a role in promoting end-joining and preventing DSBs from generating chromosomal breaks and translocations (8).

The epipodophyllotoxin etoposide is a drug that specifically inhibits the enzyme DNA topoisomerase II. Topoisomerase II, together with topoisomerase I, relieves topological constrains generated during DNA metabolism reactions, such as replication, transcription, chromosome segregation and chromatin remodelling (9). To perform its task, topoisomerase II introduces transient double strand breaks into the DNA molecule, forming a short-lived covalent complex with cleaved DNA (cleavable complex). Etoposide stabilizes the cleavable complex and, preventing religation of the broken ends, causes DSB or single strand break formation (10). Etoposide induced DSBs are mainly repaired through the non-homologous end-joining repair pathway (11-14); unrepaired lesions trigger cell cycle check-point activation, leading to the accumulation of cells in late $\mathrm{S}$ and $\mathrm{G}_{2} / \mathrm{M}$ (10). Apoptotic cell death has also been observed after exposure to etoposide (15).

Etoposide is widely used as an anticancer drug (16). A possible strategy to improve its therapeutic efficacy could be the identification of targets able to potentiate its toxicity. The observation that etoposide induces phosphorylation of H2AX (10) suggests that this histone isoform may affect cellular sensitivity to this agent. To test this hypothesis, we studied the response to etoposide in immortalized mouse embryonic fibroblasts (MEFs) derived from $H 2 A X$ knockout (KO) and wild-type mice. Immortalized MEFs were obtained by a prolonged culture propagation of primary embryonic 
fibroblasts. In fact, during culture propagation, primary MEFs undergo crisis, during which most of the cells die and those that survive give rise to cell lines able to divide indefinitely (17). Since these immortal cells could better mimic the behavior of tumor cells than primary MEFs, we chose to use them for our study.

\section{Materials and methods}

Cell lines and culture conditions. Immortalized embryonic fibroblasts derived from wild-type mice (IWT) and from H2AX KO mice (IHKO) were a generous gift of André Nussenzweig (National Institute of Health, Bethesda, MD). Cells were grown at $37^{\circ} \mathrm{C}$ under an atmosphere containing $5 \% \mathrm{CO}_{2}$ in Dulbecco's modified Eagle's medium (DMEM, Celbio), supplemented with $10 \%$ fetal bovine serum (BioWhittaker), $0.1 \mathrm{mg} / \mathrm{ml}$ penicillin (EuroClone), $100 \mathrm{U} / \mathrm{ml}$ streptomycin (EuroClone), $2 \mathrm{mM}$ glutamine and $1 \%$ nonessential amino acids (EuroClone).

Cell treatments. Twenty-four hours after seeding, cells were treated either with 1 and $2 \mu \mathrm{M}$ etoposide (CAS registry no.: 117091-64-2, Sigma) for $72 \mathrm{~h}$, or with 1 and $10 \mu \mathrm{M}$ etoposide for $24 \mathrm{~h}$, followed by 24-h recovery in drug-free complete medium. Treatment with $100 \mu \mathrm{g} / \mathrm{ml}$ bleomycin (CAS registry no.: 9041-93-4; Crinus) was performed for $3 \mathrm{~h}$. $\gamma$-ray irradiation was done as described below.

Clonogenic assay. Sensitivity to etoposide and $\gamma$-ray was analysed by clonogenic assay. Cells $\left(10^{3}\right)$ were seeded in 10-cm Petri dishes, incubated with $0.5,1,5,10 \mu \mathrm{M}$ etoposide for $24 \mathrm{~h}$, washed with PBS (phosphate-buffered saline) and further grown in complete medium for 8 days, to allow colony formation by surviving cells. To test $\gamma$-ray sensitivity, cell suspensions of $5 \times 10^{3}$ cells $/ \mathrm{ml}$ were irradiated with 2,4 and 6 Gy using a ${ }^{60} \mathrm{Co} \gamma$-ray source at a dose rate of $1.3 \mathrm{~Gy} / \mathrm{min}$. After irradiation, cell suspensions were diluted with complete medium, $10^{3}$ cells/10-cm Petri dish were seeded and grown for 10 days. Untreated controls were set up in parallel. Colonies were then fixed with $100 \%$ methanol for $10 \mathrm{~min}$ and stained whit Coomassie Blue (0.1\% Page Blue G-90, $50 \%$ methanol and $7.4 \%$ acetic acid). The percentage of colonies formed at each dose, relatively to untreated cells, was determined and used to draw survival curves. From the curves, doses reducing cell survival and to $37 \%\left(\mathrm{LD}_{37}\right)$ were calculated.

Morphological analysis. Cells grown on coverslips (8x104 cells/ $3.5-\mathrm{cm}$ Petri dish) were treated with etoposide, washed with cold PBS, fixed with $10 \%$ TCA for 10 min and dehydrated with cold 70, 90 and $100 \%$ ethanol ( 3 min each). After fixation, cells were incubated for $10 \mathrm{~min}$ with $0.1 \mu \mathrm{g} / \mathrm{ml}$ Hoechst 33258 (Sigma) in PBS in the dark, and washed 4 times for 5 min with PBS. Coverslips were mounted on microscope slides with Anti-fade. Slides were analysed using an Olympus IX71 microscope equipped with an objective x63; images were acquired with a digital camera Cool $\mathrm{SNAP}_{\mathrm{ES}}$ (Photometrics), using the MetaMorph acquisition software; Adobe Photoshop 5.0.2 was used as elaborating software. For each sample, 500 cells were analysed.
Comet assay. Cells $\left(2 \times 10^{5}\right)$ were grown for $24 \mathrm{~h}$ in $6-\mathrm{cm}$ Petri dishes, treated with etoposide, harvested on ice by scraping in $2 \mathrm{ml}$ of cold PBS, centrifuged for $3 \mathrm{~min}$ at $300 \mathrm{~g}$ at $4^{\circ} \mathrm{C}$ and washed three times with cold PBS. Then, cells were embedded in $1 \%(\mathrm{w} / \mathrm{v})$ Low Melting Point (LMP) agarose (Gibco, BRL) and immediately transferred onto glass microscope slides precoated with a layer of $1 \%(\mathrm{w} / \mathrm{v})$ standard agarose (Gibco, BRL). The cells were then lysed in a solution containing $2.5 \mathrm{M} \mathrm{NaCl}, 0.1 \mathrm{M}$ EDTA, $10 \mathrm{mM}$ Tris-base and $1 \%$ Triton X-100 ( $\mathrm{pH} \mathrm{10),} \mathrm{for} 2 \mathrm{~h}$ at $4^{\circ} \mathrm{C}$ to obtain 'nucleoids'. Thereafter, slides were equilibrated in a horizontal electrophoresis tank with fresh electrophoresis buffer $(0.3 \mathrm{M} \mathrm{NaOH}$, $1 \mathrm{mM}$ EDTA) for $40 \mathrm{~min}$, and then electrophoresed for $30 \mathrm{~min}$ at $25 \mathrm{~V}$. The nucleoids were subsequently washed three times for $5 \mathrm{~min}$ at $4^{\circ} \mathrm{C}$ each in neutralizing buffer $(0.4 \mathrm{M}$ Tris- $\mathrm{HCl}$, pH 7.5), and stained with 4',6-diamine-2-phenylindole dihydrochloride (DAPI, $5 \mu \mathrm{g} / \mathrm{ml}$ ). DAPI-stained nucleoids were visualized using a fluorescence microscope (Nikon Eclipse E400). Samples were analysed in a blind manner. For each slide, 200 nucleoids were scored, classified in 5 classes according to the relative fluorescence intensity of the tail and assigned a score in arbitrary units on the basis of the grade of the damage, from 0 (undamaged nucleus) to 4 (severely damaged nucleus). The total damage score for each slide was obtained by multiplying the number of nucleoids assigned to each class of damage by the numeric value of the damage grade and summing all the scores (reaching a maximum score of 400 , corresponding to 100 cells at grade 4) (18). Statistical significance was calculated using one-tailed Student's t-test.

Flow cytometry. Cells were grown in complete medium (1.5-2x $10^{6}$ cells/10-cm Petri plate) for $24 \mathrm{~h}$ and treated with etoposide as described above. After treatment, cells were trypsinized, centrifuged for $5 \mathrm{~min}$ at $1000 \mathrm{rpm}$ at $4^{\circ} \mathrm{C}$ and resuspended with cold $0.9 \% \mathrm{NaCl}\left(10^{6}\right.$ cells $\left./ \mathrm{ml}\right)$; cold $100 \%$ ethanol was then added to cell suspensions to a final $70 \%$ concentration. Samples were then incubated for $30 \mathrm{~min}$ at room temperature with $30 \mu \mathrm{g} / \mathrm{ml}$ propidium iodide (Sigma) and $2 \mathrm{mg} / \mathrm{ml}$ RNase A (Sigma). Samples were kept overnight at $4^{\circ} \mathrm{C}$, and then analysed using an Epics XL II flow cytometer (Coulter). Analysis was made using XL II software.

Western blot analysis. To analyse cyclin A, cyclin B1 and poly(ADP-ribose) polymerase-1 (PARP-1) expression, control and etoposide-treated cells $\left(4 \times 10^{6}\right)$ were resuspended in $100 \mu \mathrm{l}$ of lysis buffer (10 mM Tris- $\mathrm{HCl}, \mathrm{pH} 7.6,140 \mathrm{mM}$ $\mathrm{NaCl}, 0.5 \%$ Nonidet P40, 5 mM EDTA, pH 8.0) supplemented with protease inhibitor cocktail (Sigma) and $2 \mathrm{mM} \mathrm{Na}_{3} \mathrm{VO}_{4}$. Samples were kept in ice for $20 \mathrm{~min}$ and then centrifuged for $10 \mathrm{~min}$ at $8000 \mathrm{rpm}$ at $4^{\circ} \mathrm{C}$. Supernatants were recovered and protein concentration was measured using the Bradford reagent (Sigma). After heating at $95^{\circ} \mathrm{C}$ for 5 min in Laemmli buffer (60 mM Tris- $\mathrm{HCl}$, pH 6.8, 5\% (ß-mercaptoethanol, $2 \%$ SDS, $10 \%$ glycerol, $0.003 \%$ Bromophenol blue), $50 \mu \mathrm{g}$ of each sample were loaded on $10 \%$ polyacrylamide gels. After running and transfer of proteins onto nitrocellulose, membranes were incubated overnight with the following mouse monoclonal primary antibodies against: cyclin A (Sigma, diluted 1:1000); cyclin B1 (Santa Cruz, diluted 1:1000); PARP-1 (Alexis, diluted 1:1000); $\gamma$-tubulin (Sigma, 
A
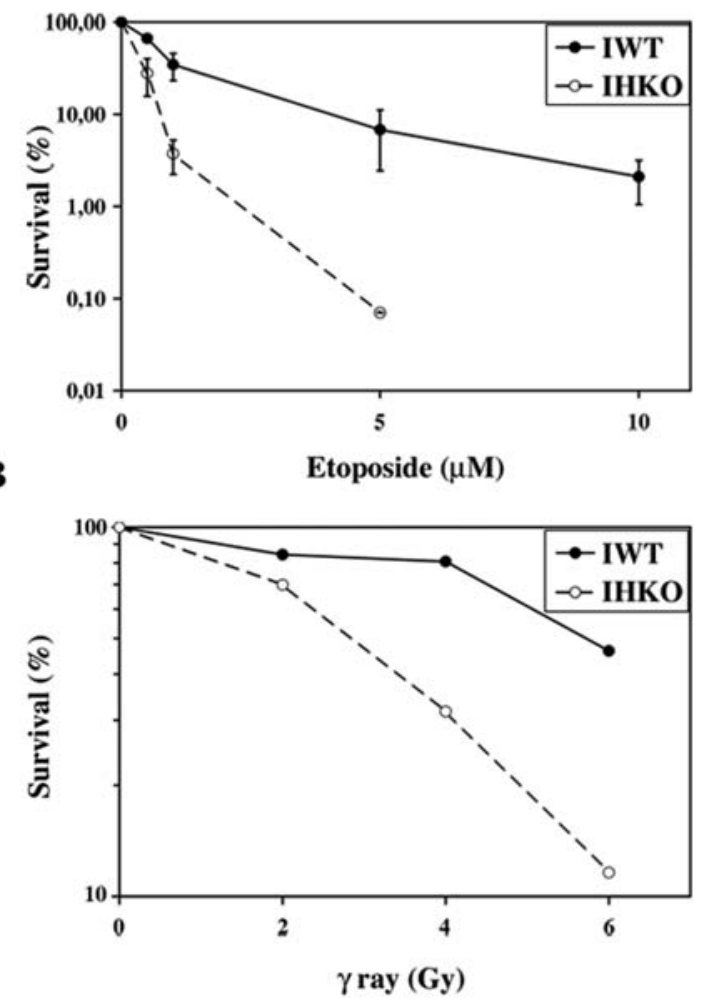

Figure 1. (A) Survival curves of IWT and IHKO cells treated with different concentrations of etoposide. Survival values at each etoposide concentration are the mean among the values obtained in three independent experiments. Standard error bars are shown. (B) Survival curves of IWT and IHKO cells treated with different doses of $\gamma$-rays.

diluted 1:15000); actin (Sigma, diluted 1:10000). Then, an HRP-conjugated anti-mouse secondary antibody (Jackson Laboratories, diluted 1:10000) was applied for $1 \mathrm{~h}$. All antibodies were diluted in TBS (140 mM NaCl, $100 \mathrm{mM}$ Tris-HCl, pH 7.5), containing 5\% skim milk and $0.1 \%$ Tween-20. Visualization of immunoreactive bands was achieved using a chemiluminescent substrate (Super Signal West Pico or Dura Extended, Pierce).

Evaluation of apoptosis. PARP-1 proteolysis, which is a hallmark of caspase activation (19), was monitored by Western blotting in total protein extracts as above described. For DNA ladder analysis, control and treated cells $\left(2.5 \times 10^{6}\right)$ were rinsed twice in cold PBS containing $5 \mathrm{mM}$ EDTA; genomic DNA was extracted and analysed by agarose gel electrophoresis as previously reported (20).

\section{Results}

The absence of $H 2 A X$ sensitizes cells to etoposide. To analyse cellular sensitivity to etoposide, we evaluated survival of IWT and IHKO cells to increasing concentrations of the drug by clonogenic assays. As shown in Fig. 1A, cell survival was affected in a dose-dependent manner and was reduced to greater extent in IHKO cells than in IWT cells. Etoposide $\mathrm{LD}_{37}$ was $\sim 0.2 \mu \mathrm{M}$ for IHKO and $\sim 1 \mu \mathrm{M}$ for IWT, indicating that cells deficient for $\mathrm{H} 2 \mathrm{AX}$ are more sensitive to Etoposide than wild-type cells. In Fig. 1B, survival curves to $\gamma$-ray of
IHKO and IWT cells are shown, which confirm the greater sensitivity to ionizing radiations of $\mathrm{H} 2 \mathrm{AX} \mathrm{KO}$ cells relatively to wild-type cells.

IHKO cells show a higher persistence of etoposide induced DNA breaks than IWT cells. Given the increased sensitivity to etoposide of H2AX deficient cells, we analysed DNA break induction and repair in IHKO and IWT cells exposed to etoposide. To this aim, we applied the comet assay to IWT and IHKO cells treated with 1 or $10 \mu \mathrm{M}$ etoposide for $24 \mathrm{~h}$ and to parallel samples further incubated for $24 \mathrm{~h}$ in drug-free medium after the treatment. As illustrated in Fig. 2A, the basal level of DNA breaks ( $0 \mu \mathrm{M}$ etoposide) is slightly higher in IHKO cells compared to wild-type cells, as expected on the basis of the known genome instability characterizing $\mathrm{H} 2 \mathrm{AX}$ null cells (5). After 24-h treatment with $1 \mu \mathrm{M}$ or $10 \mu \mathrm{M}$ etoposide (white columns), a significative increase $(\mathrm{p}<0.05$ and $\mathrm{p}<0.001$, respectively) in the extent of the DNA damage was observed in both cell lines compared to control cells. After exposure to the highest etoposide concentration, the entity of the damage was significantly higher in mutant IHKO cells compared to IWT cells, indicating that the absence of $\mathrm{H} 2 \mathrm{AX}$ renders cells more susceptible to etoposide induced DNA damage, possibly because DNA repair is impaired. To investigate the ability of both IWT and IHKO cells to repair DNA breaks induced by etoposide, we performed the comet assay on cells maintained in drug-free medium for $24 \mathrm{~h}$ after etoposide treatment. As illustrated in Fig. 2A (black columns), IWT showed a residual amount of DNA breaks, which was significantly increased $(\mathrm{p}<0.05)$ vs. control cells only at the highest etoposide concentration, while, in IHKO cells, DNA breaks were significantly higher than in control cells at both Etoposide concentrations ( $\mathrm{p}<0.05$ and $\mathrm{p}<0.001$, after 1 and $10 \mu \mathrm{M}$ etoposide, respectively). In addition, at $10 \mu \mathrm{M}$ etoposide, the residual DNA breaks were significantly higher in IHKO compared to IWT cells $(\mathrm{p}<0.05)$. After exposure to $10 \mu \mathrm{M}$ etoposide, $74.3 \%$ of the lesions were removed in IWT cells, while only $59.4 \%$ in IHKO cells. Taken together, these observations indicate that H2AX null cells are impaired in the removal of etoposide induced DNA breaks.

Etoposide induces micronuclei and nuclear fragmentation. To study the cytological effects of etoposide, we stained IWT and IHKO cells exposed to etoposide with Hoechst 33258 and we analysed nuclear morphology. We found two main consequences of etoposide treatment: micronuclei formation and nuclear fragmentation. Fig. 2B shows examples of etoposide treated IWT (panel c) and IHKO (panel d) cells with micronuclei. Of note, the basal level of micronuclei was higher in IHKO ( 10\%) compared to IWT cells $(\sim 2-3 \%)$, probably because of the spontaneous genomic instability due to the absence of H2AX (Fig. 2C and E). After treatment with $1 \mu \mathrm{M}$ etoposide, the percentage of cells with micronuclei was $27.3 \%$ in IWT and $29.7 \%$ in IHKO after 24-h treatment (indicated by the suffix $\mathrm{t}_{0}$ ), and $\sim 23 \%$ in both cell lines, after recovery in drug-free medium (indicated by the suffix $t_{24}$ ). In untreated cells, almost all cells had only one micronucleus, while in IWT and IHKO etoposide exposed cells, the percentage of cells with more than 1 micronucleus was 
A

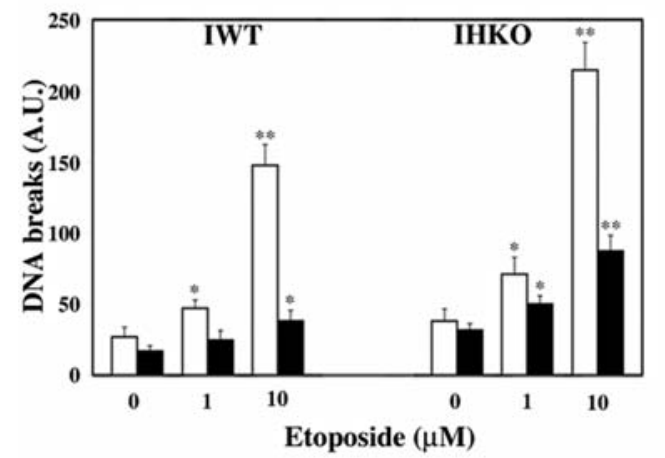

C

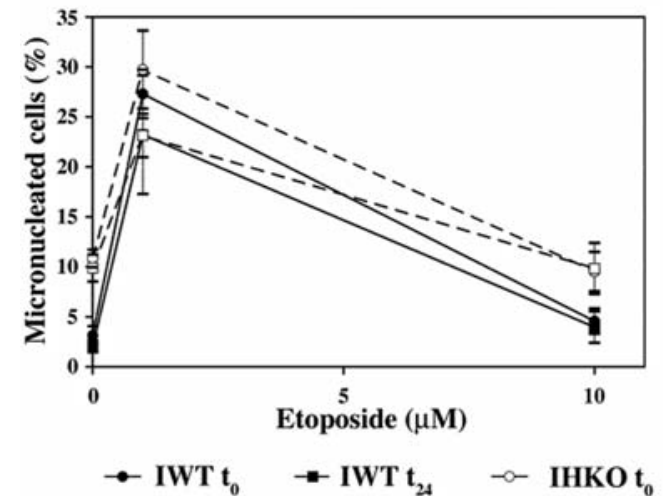

E

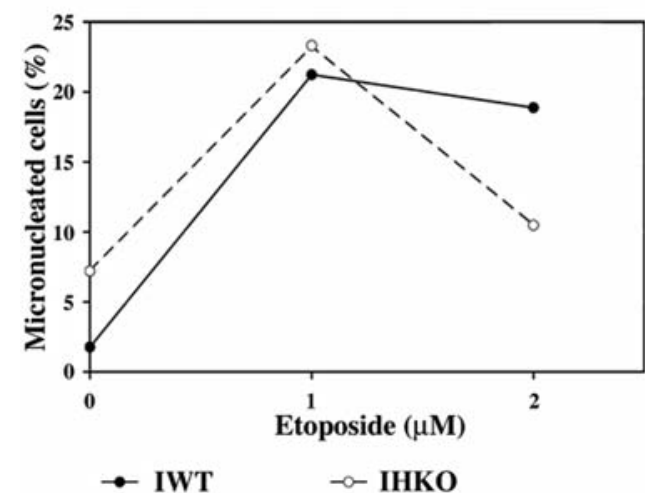

B
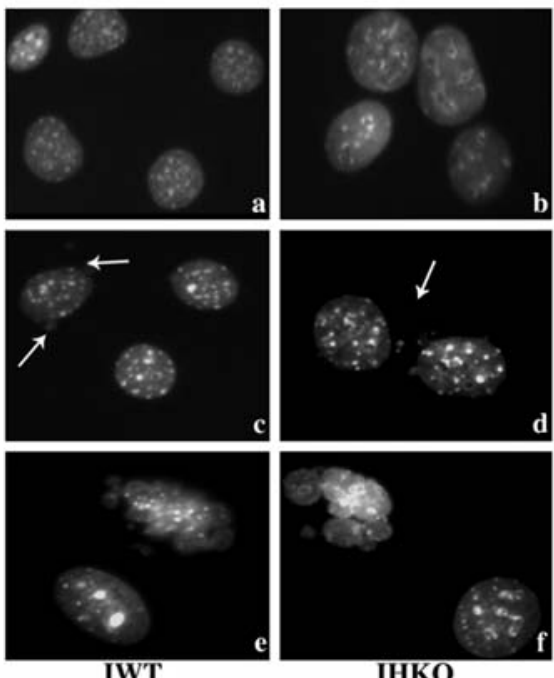

D

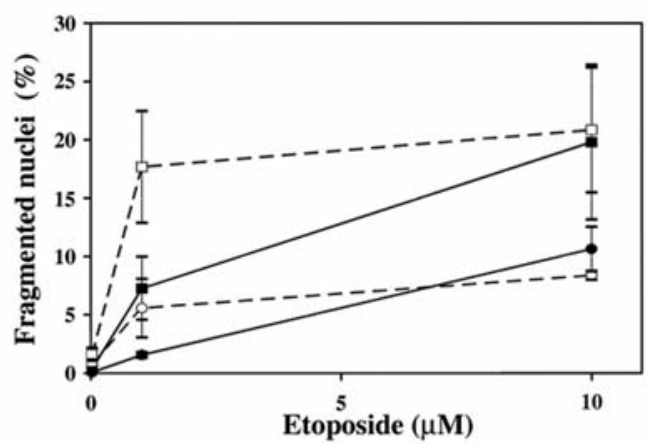

$-0-$ IHKO t $_{24}$

F

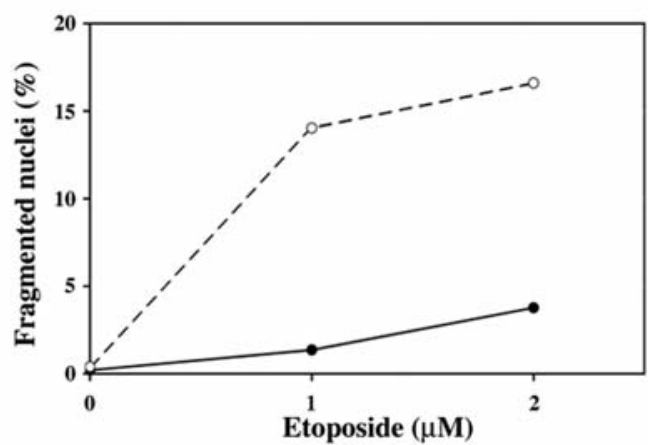

Figure 2. (A) Comet assay analysis of DNA breaks induced by etoposide in IWT and IHKO cells. The amount of DNA breaks is expressed in arbitrary units (AU). Each value is the mean among the values obtained in three independent experiments. White columns, DNA breaks measured at the end of the 24-h treatment; black columns, DNA breaks measured at the end of the recovery period. Standard error bars are shown; ${ }^{*} \mathrm{p}<0.05$; ${ }^{* *} \mathrm{p}<0.001$ in comparison to control cells (Student's t-test). (B) Cytological effects of etoposide. Cells were stained with Hoechst 33258, as described in Materials and methods; examples of nuclei of untreated cells (panels a and b); examples of etoposide treated cells with micronuclei (panels c and d) or nuclear fragmentation (panels e and f). (C) Percentage of micronucleated cells; and (D) percentage of cells with nuclear fragmentation in IWT and IHKO cells exposed to $1 \mu \mathrm{M}$ or $10 \mu \mathrm{M}$ etoposide for $24 \mathrm{~h}$. $\mathrm{t}_{0}$, cell samples analysed at the end of the treatment; $\mathrm{t}_{24}$, cell samples analysed after 24-h recovery in drug-free medium. Each value is the mean among the values obtained in four independent experiments. Standard error bars are shown. (E) Percentage of micronucleated cells and (F) percentage of cells with nuclear fragmentation in IWT and IHKO cells exposed to 1 or $2 \mu \mathrm{M}$ etoposide for $72 \mathrm{~h}$.

$\sim 10$ and $14 \%$, respectively. In cells treated with the highest etoposide concentration $(10 \mu \mathrm{M})$, the percentage of cells with micronuclei was similar to that observed in untreated cells, both at $t_{0}$ and $t_{24}$ (Fig. 2C). Exposure of IWT and IHKO cells to $1 \mu \mathrm{M}$ etoposide for $72 \mathrm{~h}$ still induced micronuclei formation in both cell lines $(21.2 \%$ in IWT and $23.3 \%$ in IHKO), while after treatment with $2 \mu \mathrm{M}$ etoposide the frequency of micronuclei was increased, compared to basal levels, only in IWT cells (19\%) (Fig. 2E).

The frequency of cells with nuclear fragmentation (Fig. 2B, IWT in panel e, IHKO in panel f) is reported in Fig. 2D and F. Cells with fragmented nuclei were absent in untreated IWT and IHKO cells and reached the highest frequency after the recovery time (Fig. 2D). After 24-h treatment with $1 \mu \mathrm{M}$ 
A

IWT
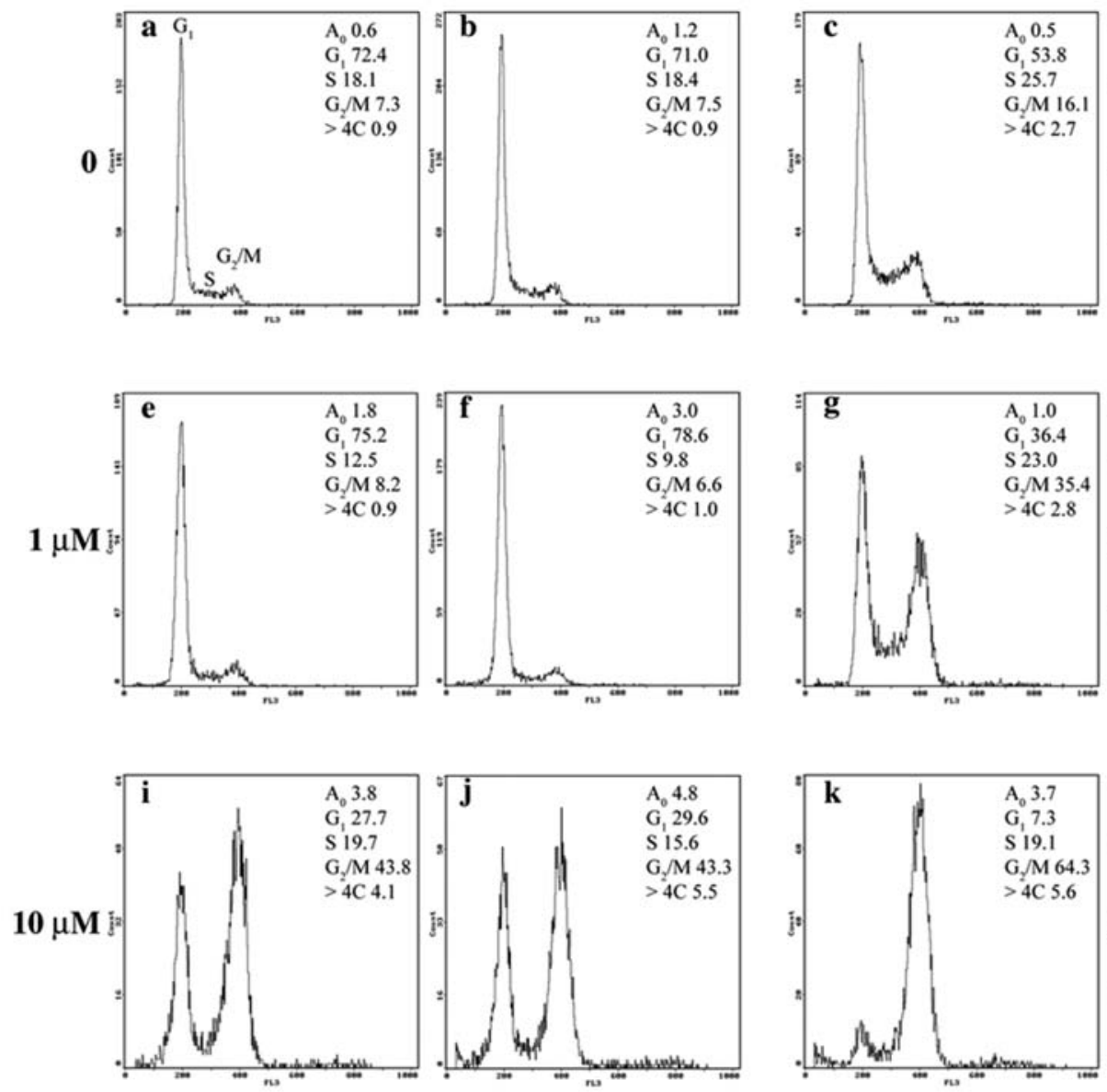

$\mathbf{t}_{0}$

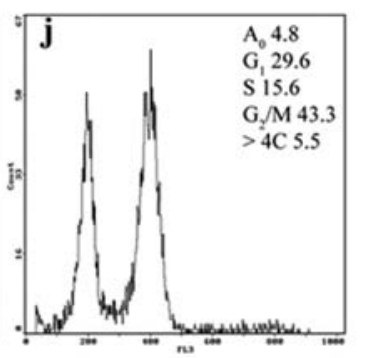

$\mathbf{t}_{24}$

\section{B}

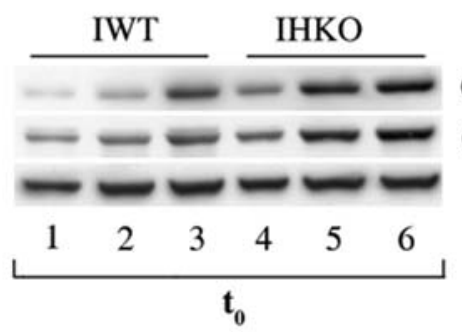

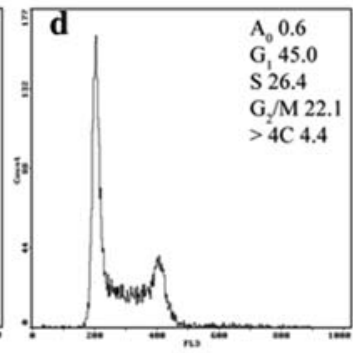
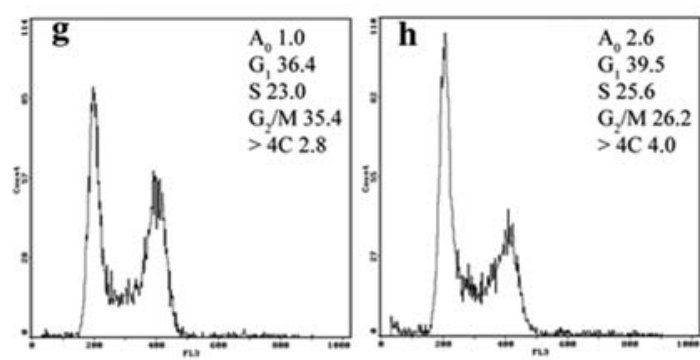

\section{IHKO}
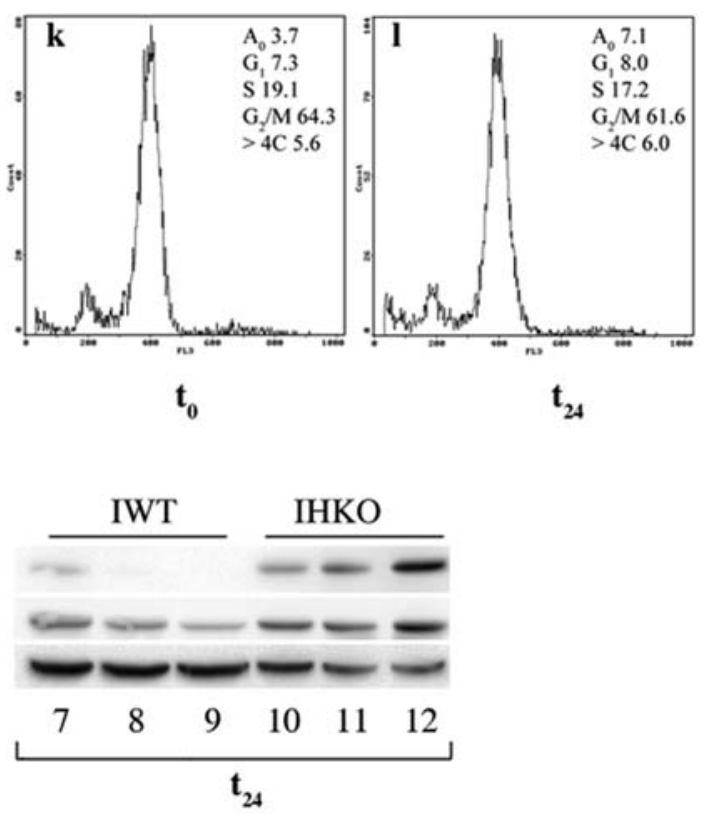

Figure 3. (A) Cell cycle distribution of IWT and IHKO cells exposed to etoposide for $24 \mathrm{~h}$. $\mathrm{t}_{0}$, analysis at the end of the treatment; $\mathrm{t}_{24}$, analysis after $24-\mathrm{h}$ recovery in drug-free medium. (B) Western blot analysis of cyclin B1 and cyclin A expression in IWT and IHKO cells exposed to etoposide for 24 h. $\mathrm{t}_{0}$, analysis at the end of the treatment; $\mathrm{t}_{24}$, analysis after 24-h recovery in drug-free medium. Lanes 1, 4, 7 and 10, control cells; lanes 2, 5, 8 and 11, cells exposed to $1 \mu \mathrm{M}$ etoposide; lanes 3, 6, 9 and 12, cells exposed to $10 \mu \mathrm{M}$ etoposide. Actin was used as internal control for protein loading.

etoposide, their level showed a small increase, greater in IHKO cells $(5.5 \%)$ than in IWT $(1.5 \%)$; at this drug concentration, the different response in the two cell lines became highly evident after the recovery time: $17.7 \%$ of cells with nuclear fragmentation in IHKO cells vs. $7.3 \%$ in IWT cells (Fig. 2D). No substantial differences were observed in the two cell lines after exposure to $10 \mu \mathrm{M}$ etoposide, being the percentage of cells with nuclear fragmentation 8.4 in IWT and $10.6 \%$ in IHKO, just at the end of treatment, and 19.8 and $20.9 \%$ after the recovery time. In cells treated with $1 \mu \mathrm{M}$ and $2 \mu \mathrm{M}$ etoposide for $72 \mathrm{~h}$, the percentage of IHKO cells with fragmented nuclei was higher than that observed in IWT cells ( 14 vs. $1.4 \%$ at $1 \mu \mathrm{M}$, and 16.6 vs. $3.8 \%$ at $2 \mu \mathrm{M}$ ) (Fig. 2F).

H2AX deficient cells show a more drastic cell cycle impairment upon etoposide treatment. To investigate the effect of etoposide on the cell cycle, samples treated with the drug were analysed by flow cytometry. As illustrated in Fig. 3A, both cell lines accumulated in the $\mathrm{G}_{2} / \mathrm{M}$ phase of cell cycle after etoposide treatment for $24 \mathrm{~h}$, but with a different doseresponse. In fact, in IHKO samples harvested immediately at 
IWT
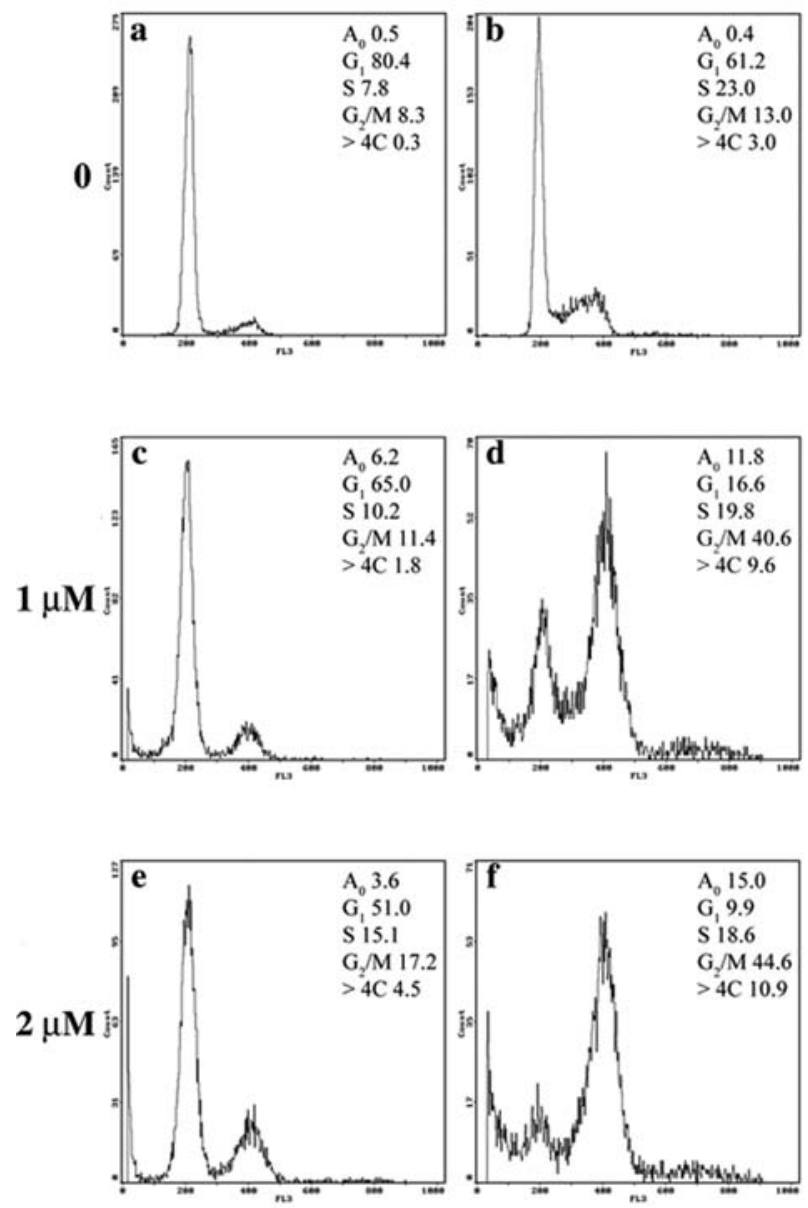

Figure 4. Cell cycle distribution of IWT and IHKO cells exposed to etoposide for $72 \mathrm{~h}$.

the end of the treatment $\left(t_{0}\right)$, the fraction of cells in $G_{2} / M$ reached $35.4 \%$ at the lowest concentration of etoposide $(1 \mu \mathrm{M}$; panel $\mathrm{g}$ ) and $64.3 \%$ at $10 \mu \mathrm{M}$ etoposide (panel $\mathrm{k}$ ), while, in IWT cells, accumulation of cells in $\mathrm{G}_{2} / \mathrm{M}$ occurred only after exposure to the highest etoposide concentration $(43.8 \%$; panel i). After the recovery time in the absence of the drug (Fig. 3A, $\mathrm{t}_{24}$ ), in IHKO cells, a decrease in the fraction of cells in $\mathrm{G}_{2} / \mathrm{M}$ was observed after treatment with $1 \mu \mathrm{M}$ etoposide (26.2\%; panel h), indicating that cells were re-entering into the cell cycle, while a persistent accumulation in $\mathrm{G}_{2} / \mathrm{M}$ was detected after exposure to $10 \mu \mathrm{M}$ etoposide (61.6\%; panel 1 ). In IWT cells exposed to the highest etoposide concentration, the fraction of cells in $\mathrm{G}_{2} / \mathrm{M}$ remained high after the recovery time (43.3\%; panel j), while again no accumulation of cells in $\mathrm{G}_{2} / \mathrm{M}$ was present after $1 \mu \mathrm{M}$ etoposide (panel $\mathrm{f}$ ).

The different response to etoposide between the two cell lines resulted even amplified when the cells were treated with 1 and $2 \mu \mathrm{M}$ etoposide for $72 \mathrm{~h}$ (Fig. 4). IWT cells treated with $1 \mu \mathrm{M}$ and $2 \mu \mathrm{M}$ etoposide showed $11.4 \%$ (panel c) and $17.2 \%$ (panel e) of cells in the $\mathrm{G}_{2} / \mathrm{M}$ phase, respectively, whereas in parallel IHKO samples the percentages were $40.6 \%$ (panel d) and $44.6 \%$ (panel f), respectively.

To clarify whether the effects induced by etoposide were attributable to an impaired progression through the $G_{2} / M$ phases, the levels of cyclin A and cyclin B1 were assessed by
Western blotting. Cyclin A is necessary to S-phase progression and $\mathrm{S} / \mathrm{G}_{2}$ transition, and is degraded at entry in mitosis (21), while cyclin B1 levels increase from late $G_{2}$ to metaphase, and it is degraded in anaphase to allow mitotic exit $(22,23)$. The results showed that the accumulation of cells in the $\mathrm{G}_{2} / \mathrm{M}$ compartment was accompanied by a parallel increase in cyclin A and B1 content, both in IWT exposed to $10 \mu \mathrm{M}$ etoposide (Fig. 3B, lane 3) and IHKO cells treated with both etoposide concentrations for $24 \mathrm{~h}$ (Fig. 3B, lanes 5 and 6), as well as in IHKO cells treated with the drug for $72 \mathrm{~h}$ (data not shown). IHKO cells exposed to $10 \mu \mathrm{M}$ etoposide showed persistently high levels of cyclin A and B1 even during recovery time (Fig. 3B, lane 12), indicating that cells were still arrested in the $\mathrm{G}_{2} / \mathrm{M}$ compartment. In contrast, low to undetectable levels of these cyclins were observed in IWT cells, during recovery after drug treatment (Fig. 3B, lane 9). Both in wild-type and $H 2 A X \mathrm{KO}$ cells exposed to $10 \mu \mathrm{M}$ Etoposide, the accumulation of cells in $\mathrm{G}_{2} / \mathrm{M}$ persisted also after the recovery period in drug-free medium; however, unexpectedly, in wild-type cells no accumulation of cyclin A and $\mathrm{B} 1$ was detected. A possible explanation to this observation is that IWT cells slowly exited mitosis and re-entered $G_{1}$ phase, i.e. progressed to phases where these cyclins are degraded or not expressed $(21,22)$. This hypothesis is supported by cell cycle analysis at 48 -h post-treatment, showing an increased fraction of cells in $\mathrm{G}_{1}$ in IWT cells, while in IHKO cells the extent of DNA damage heavily affected DNA stainability, and hence cell cycle analysis (data not shown).

Of note, flow cytometric analysis showed a detectable fraction of cells with a DNA content $>4 \mathrm{C}$, which is suggestive of polyploidization. The percentage of these cells was similar in both cell lines after the 24-h treatment (Fig. 3A), while the prolonged treatment caused an increase of this cell fraction mainly in IHKO cells, where it reached $\sim 11 \%$ vs. $4.5 \%$ in IWT (Fig. 4). This observation is in agreement with an impaired cell cycle progression after etoposide treatment, induced preferentially in IHKO cells compared to IWT. DNA profiles revealed also the presence of cells with DNA content $<2 \mathrm{C}$, generally considered as cells with fragmented DNA, as it is the case of apoptotic cells (Figs. 3A and 4). These cells, named $\mathrm{A}_{0}$, were evident at the highest concentration of etoposide $(10 \mu \mathrm{M})$ and mainly after $24 \mathrm{~h}$ of recovery; compared to IWT (Fig. 3A, panel j), IHKO cells (Fig. 3A, panel 1) showed a higher fraction of cells with a DNA content $<2 \mathrm{C}$ (7.1 vs. 4.8\%). This difference was more consistent in cells recovered after a prolonged treatment with $2 \mu \mathrm{M}$ etoposide, being the $\mathrm{A}_{0}$ values $3.6 \%$ in IWT (Fig. 4, panel e) vs. $15 \%$ in IHKO (Fig. 4, panel f).

To explore the possibility that etoposide induced apoptosis in our treatment conditions, we analysed two specific markers of this death program, i.e. internucleosomal DNA fragmentation and PARP-1 proteolysis. As clearly illustrated in Fig. 5A, we did not observe DNA internucleosomal degradation either in IWT or IHKO cells exposed to 1 and $10 \mu \mathrm{M}$ etoposide for $24 \mathrm{~h}$, both at the end of the treatment (lanes 2, 3,5 and 6) and after the recovery period (lanes $9,10,12$ and 13), or in cells exposed to 1 and $2 \mu \mathrm{M}$ etoposide for $72 \mathrm{~h}$ (lanes $15,16,18$ and 19). Accordingly, we did not find PARP-1 proteolysis in any treatment condition (Fig. 5B). 
A
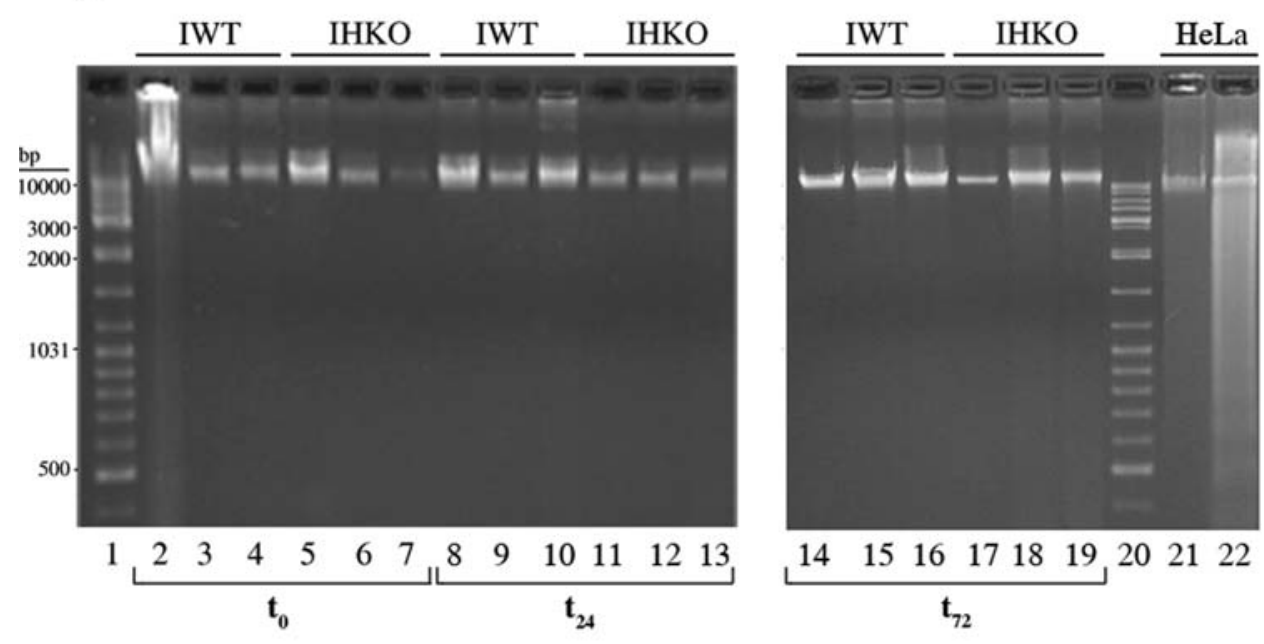

B

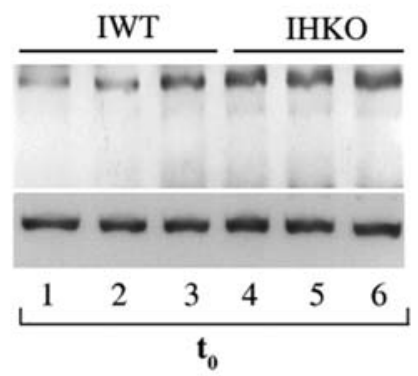

PARP1

$\gamma$-tubulin
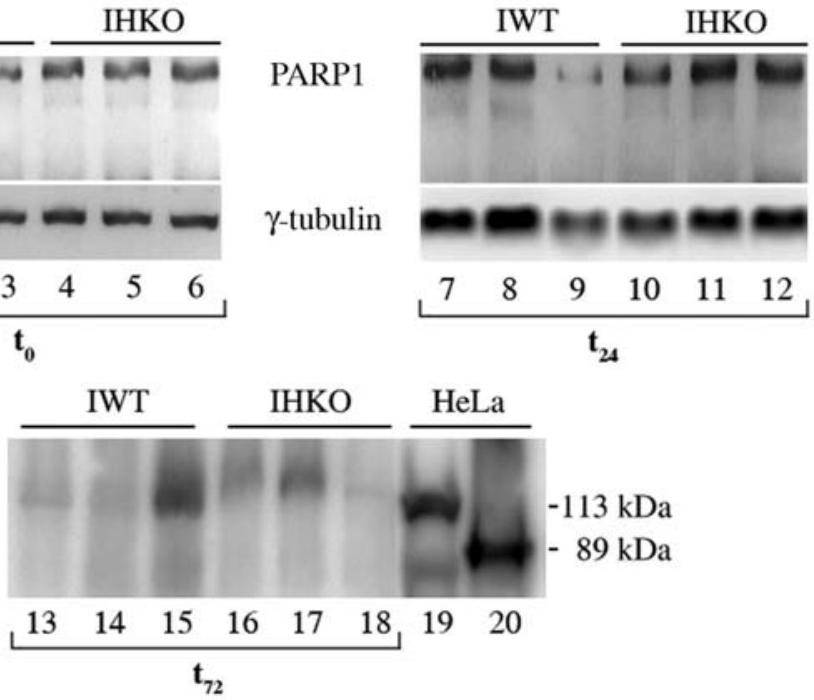

Figure 5. (A) Gel electrophoresis analysis of DNA extracted from IWT and IHKO cells exposed to etoposide for $24 \mathrm{~h}$ (lanes 2-13) or for 72 $\mathrm{h}$ (lanes 14-19). $\mathrm{t}_{0}$, analysis at the end of the treatment; $\mathrm{t}_{24}$, analysis after 24-h recovery in drug-free medium; $\mathrm{t}_{72}$, analysis after 72-h treatment. Lanes 2, 5, 8, 11, 14 and 17, control cells; lanes $3,6,9,12,15$ and 18 , cells exposed to $1 \mu \mathrm{M}$ etoposide; lanes $4,7,10$ and 13 , cells exposed to $10 \mu \mathrm{M}$ etoposide; lanes 16 and 19 , cells exposed to $2 \mu \mathrm{M}$ etoposide; lanes 1 and 20, molecular weight markers; lane 21, control HeLa cells; lane 22, DNA ladder in apoptotic HeLa cells. (B) Western blot analysis of PARP-1 in IWT and IHKO cells exposed to etoposide for $24 \mathrm{~h}$ (lanes 1-12) or for $72 \mathrm{~h}$ (lanes 13-18). $\mathrm{t}_{0}$, analysis at the end of the treatment; $\mathrm{t}_{24}$, analysis after 24-h recovery in drug-free medium; $\mathrm{t}_{72}$, analysis after 72-h treatment. Lanes 1, 4, 7, 10, 13 and 16, control cells; lanes 2, 5, 8, 11, 14 and 17, cells exposed to $1 \mu \mathrm{M}$ etoposide; lanes 3, 6, 9 and 12, cells exposed to $10 \mu \mathrm{M}$ etoposide; lanes 15 and 18, cells exposed to $2 \mu \mathrm{M}$ etoposide; lane 19 , control HeLa cells; lane 20, HeLa cells treated with $100 \mu \mathrm{M}$ etoposide for $3 \mathrm{~h}$ used as positive control for PARP-1 proteolysis in apoptosis. $113 \mathrm{kDa}$, intact PARP-1; $89 \mathrm{kDa}$, proteolysed PARP-1 fragment.

\section{Discussion}

Etoposide, an inhibitor of DNA topoisomerase II, induces DNA double strand breaks that activate $\mathrm{H} 2 \mathrm{AX}$ phosphorylation (10). The aim of this study was to determine whether H2AX plays a role in the cellular response to etoposide. To this regard, we treated $H 2 A X \mathrm{KO}$ and wild-type immortalized MEFs with etoposide under various conditions of concentration and treatment time. We have shown that survival to etoposide is reduced in $H 2 A X \mathrm{KO}$ cells compared to wild-type. In addition, we found both a higher level of DNA breaks in mutant cells, as well as a reduced level of lesions repaired during the recovery time. These observations suggest that $\mathrm{H} 2 \mathrm{AX}$ takes part to the repair of DNA breaks induced by etoposide. Because there is evidence that etoposide lesions are mainly repaired by the NHEJ mechanism (11-14), these results indicate that $\mathrm{H} 2 \mathrm{AX}$ is also involved in this DNA repair pathway.

At the cytological level, etoposide induces two main phenomena, the formation of micronuclei, which are small nuclei associated with a nucleus of normal shape, and nuclear fragmentation. Micronuclei can originate either from mis-segregating chromosomes or from acentromeric chromosomal fragments derived from DNA DSBs, and are generally regarded as markers of chromosomal instability (24). Cells with nuclear fragmentation lacked a morphologically normal nucleus, but contained several nuclear fragments of variable size. 
Both in mutant and wild-type cells, micronuclei formation is the main response to the lower etoposide concentration. Despite H2AX deficient cells showed a basal level of micronuclei higher than wild-type cells, in both lines the frequency of micronuclei reached similar values. However, it should be taken into account that, in $\mathrm{H} 2 \mathrm{AX}$ deficient cells, the percentage of cells with multiple micronuclei was higher than in wild-type cells, thus suggesting that further induction of micronuclei occurred in already micronucleated cells.

In wild-type cells, micronuclei and nuclear fragmentation were clearly dose-dependent and appeared mutually exclusive, being present at the lower or at the higher etoposide concentration, respectively. This suggests that the amount of DNA damage induced by etoposide determines the type of effect observed at the cytological level. In mutant cells, etoposide induced nuclear fragmentation already at the lowest concentration, in agreement with the increased number of breaks observed and the reduced capacity of these cells to repair etoposide induced DNA damage. The presence of cells with nuclear fragmentation in mutant cells exposed to $1 \mu \mathrm{M}$ etoposide may also contribute to explain why the fraction of cells with micronuclei is not higher than in wildtype cells.

The enhanced response to a low etoposide concentration in mutant cells compared to wild-type cells was particularly evident when cells were exposed to the drug for a prolonged time. In fact, after 72-h exposure at 1 and $2 \mu \mathrm{M}$ etoposide, in wild-type cells, micronuclei were induced at high frequency and nuclear fragmentation remained low. In contrast, in mutant cells, the lowest concentration caused the formation of both micronuclei and nuclear fragmentation, and the highest concentration caused mainly nuclear fragmentation.

Nuclear fragmentation can be the cytological manifestation of mitotic death (25), which is a form of death linked to the incapacity of cells to correctly terminate mitosis. Mitotic death has been described in cells undergoing a $G_{2}$ arrest in the cell cycle due to treatment with different types of damaging agents (26-28), including etoposide (29). This can also be the case in our experimental system, as shown by the results of flow cytometric analysis.

Accumulation of etoposide treated cells in the $\mathrm{G}_{2} / \mathrm{M}$ phases of the cell cycles was shown by flow cytometry and was confirmed by the acccumulation of cyclin A and cyclin B. The results obtained treating cells with the drug for $24 \mathrm{~h}$ suggest that the arrest in $\mathrm{G}_{2} / \mathrm{M}$ precedes nuclear fragmentation. In fact, both in wild-type cells exposed to $10 \mu \mathrm{M}$ etoposide and in H2AX deficient cells exposed to both etoposide concentrations, accumulation of cells in $\mathrm{G}_{2} / \mathrm{M}$ was already evident at the end of the treatment, while nuclear fragmented cells reached the highest levels after 24-h recovery in drug-free medium. Cells arrested in $\mathrm{G}_{2} / \mathrm{M}$ probably undergo mitotic death being unable to complete cell cycle in the presence of DNA damage.

In our treatment conditions, no sign of apoptosis were detected either in wild-type or mutant cells exposed to etoposide, confirming that different types of cell death can be induced by the same agent, depending on the concentration used (26).

Taken together, the results reported in this study indicate that low etoposide concentrations cause DNA damage that mainly induces micronuclei formation, while at higher concentrations of the drug, the damage causes a perturbation of the cell cycle leading to nuclear fragmentation and cell death. Comparison of the results obtained in wild-type and $H 2 A X \mathrm{KO}$ cells indicate that $\mathrm{H} 2 \mathrm{AX}$ plays a role in the cellular response to etoposide; $H 2 A X$ null cells are more sensitive to etoposide than wild-type cells and show a cell cycle perturbation at lower concentrations of the drug.

Evidence has been reported that inhibition of $H 2 A X$ expression in tumors, or treatment with peptide inhibitors of $\gamma \mathrm{H} 2 \mathrm{AX}$, can increase radiosensitivity $(30,31)$, indicating that $\mathrm{H} 2 \mathrm{AX}$ can be a target to sensitize cells to radiotherapy. Our observation that $\mathrm{H} 2 \mathrm{AX}$ deficiency increases mitotic death after low etoposide concentrations allows the speculation that a block of H2AX function may be a useful tool to potentiate the effects of chemotherapeutic agents, like etoposide.

\section{Acknowledgements}

We are very grateful to André Nussenzweig (National Institute of Health, Bethesda, MD), who gave us the $H 2 A X$ null cells used in this study. We acknowledge the following Italian Institutions for the grants supporting our research: Fondazione Cariplo (2006-0734), Regione Lombardia (Project Metadistretti no. 4238) and Ministero dell'Università e della Ricerca Scientifica (PRIN 2006/069475).

\section{References}

1. Rogakou EP, Pilch DR, Orr AH, Ivanova VS and Bonner WM: DNA double-stranded breaks induce histone H2AX phosphorylation on serine 139. J Biol Chem 273: 5858-5868, 1998.

2. Redon C, Pilch DR, Rogakou EP, Orr AH, Lowndes NF and Bonner WM: Yeast histone 2A serine 129 is essential for the efficient repair of check-point-blind DNA damage. EMBO Rep 4: 678-684, 2003.

3. Downs JA, Nussenzweig MC and Nussenzweig A: Chromatin dynamics and the preservation of genetic information. Nature 447: 951-958, 2007

4. Fernandez-Capetillo O, Lee A, Nussenzweig $\mathrm{M}$ and Nussenzweig A: H2AX: the histone guardian of the genome. DNA Repair 3: 959-967, 2004.

5. Celeste A, Petersen S, Romanienko PJ, Fernandez-Capetillo O, Chen HT, Sedelnikova OA, Reina-San-Martin B, Coppola V, Meffre E, Difilippantonio MJ, Redon C, Pilch DR, Olaru A, Eckhaus M, Camerini-Otero RD, Tessarollo L, Livak F, Manova K, Bonner WM, Nussenzweig MC and Nussenzweig A: Genomic instability in mice lacking histone H2AX. Science 296: 922-927, 2002.

6. Bassing CH, Chua KF, Sekiguchi J, Suh H, Whitlow SR, Fleming JC, Monroe BC, Ciccone DN, Yan C, Vlasakova K, Livingston DM, Ferguson DO, Scully R and Alt FW: Increased ionizing radiation sensitivity and genomic instability in the absence of histone H2AX. Proc Natl Acad Sci USA 99: 8173-8178, 2002.

7. Fernandez-Capetillo O, Chen HT, Celeste A, Ward I, Romanienko PJ, Morales JC, Naka K, Xia Z, Camerini-Otero RD, Motoyama N, Carpenter PB, Bonner WM, Chen J and Nussenzweig A: DNA damage-induced G2-M check-point activation by histone H2AX and 53BP1. Nat Cell Biol 4: 993-997, 2002.

8. Franco S, Gostissa M, Zha S, Lombard DB, Murphy MM, Zarrin AA, Yan C, Tepsuporn S, Morales JC, Adams MM, Lou Z, Bassing CH, Manis JP, Chen J, Carpenter PB and Alt FW: $\mathrm{H} 2 \mathrm{AX}$ prevents DNA breaks from progressing to chromosome breaks and translocations. Mol Cell 21: 201-214, 2006.

9. Wang JC: Cellular roles of DNA topoisomerases: a molecular perspective. Nat Rev Mol Cell Biol 3: 430-440, 2002.

10. Montecucco A and Biamonti G: Cellular response to etoposide treatment. Cancer Lett 252: 9-18, 2007. 
11. Adachi N, Suzuki H, Iiizumi S and Koyama H: Hypersensitivity of non-homologous DNA end-joining mutants to VP-16 and ICRF-193: implications for the repair of topoisomerase IImediated DNA damage. J Biol Chem 278: 35897-35902, 2003.

12. Adachi N, Iiizumi S, So S and Koyama H: Genetic evidence for involvement of two distinct nonhomologous end-joining pathways in repair of topoisomerase II-mediated DNA damage. Biochem Biophys Res Commun 318: 856-861, 2004.

13. Kantidze OL, Iarovaia OV and Razin SV: Assembly of nuclear matrix-bound protein complexes involved in non-homologous end joining is induced by inhibition of DNA topoisomerase II. J Cell Physiol 207: 660-667, 2006.

14. Kantidze OL and Razin SV: Chemotherapy-related secondary leukemias: a role for DNA repair by error-prone non-homologous end joining in topoisomerase II-induced chromosomal rearrangements. Gene 391: 76-79, 2007.

15. Negri C, Bernardi R, Donzelli M and Scovassi AI: Induction of apoptotic cell death by DNA topoisomerase II inhibitors. Biochimie 77: 893-899, 1995.

16. Baldwin EL and Osheroff N: Etoposide, topoisomerase II and cancer. Curr Med Chem Anticancer Agents 5: 363-372, 2005.

17. Sherr CJ and De Pinho RA: Cellular senescence: mitotic clock or culture shock? Cell 102: 407-410, 2000.

18. Collins AR: The comet assay for DNA damage and repair: principles, applications, and limitations. Mol Biotechnol 26: 249-261, 2004.

19. Soldani C and Scovassi AI: Poly(ADP-ribose) polymerase-1 cleavage during apoptosis: an update. Apoptosis 7: 321-328, 2002.

20. Donzelli M, Bernardi R, Negri C, Prosperi E, Padovan L, Lavialle $\mathrm{C}$, Brison $\mathrm{O}$ and Scovassi AI: Apoptosis-prone phenotype of human colon carcinoma cells with a high level amplification of the c-myc gene. Oncogene 18: 439-448, 1999.

21. Woo RA and Poon RY: Cyclin-dependent kinases and S phase control in mammalian cells. Cell Cycle 2: 316-324, 2003.
22. Chang DC, Xu N and Luo KQ: Degradation of cyclin B is required for the onset of anaphase in mammalian cells. J Biol Chem 278: 37865-37873, 2003.

23. Bassermann F, Peschel C and Duyster J: Mitotic entry: a matter of oscillating destruction. Cell Cycle 4: 1515-1517, 2005.

24. Muller WU, Nusse M, Miller BM, Slavotinek A, Viaggi S and Streffer C: Micronuclei: a biological indicator of radiation damage. Mutat Res 366: 163-169, 1996.

25. Castedo M, Perfettini JL, Roumier T, Andreau K, Medema R and Kroemer G: Cell death by mitotic catastrophe: a molecular definition. Oncogene 23: 2825-2837, 2004.

26. Tounekti O, Pron G, Belehradek J Jr and Mir LM: Bleomycin, an apoptosis-mimetic drug that induces two types of cell death depending on the number of molecules internalized. Cancer Res 53: 5462-5469, 1993.

27. Mackey MA and Ianzini F: Enhancement of radiation-induced mitotic catastrophe by moderate hyperthermia. Int J Radiat Biol 76: 273-280, 2000.

28. Ianzini F, Bertoldo A, Kosmacek EA, Phillips SL and Mackey MA: Lack of p53 function promotes radiation-induced mitotic catastrophe in mouse embryonic fibroblast cells. Cancer Cell Int 6: 11, 2006

29. Lock RB, Galperina OV, Feldhoff RC and Rhodes LJ: Concentration-dependent differences in the mechanisms by which caffeine potentiates etoposide cytotoxicity in HeLa cells. Cancer Res 54: 4933-4939, 1994.

30. Yoshida K and Morita T: Control of radiosensitivity of F9 mouse teratocarcinoma cells by regulation of histone H2AX gene expression using a tetracycline turn-off system. Cancer Res 64: 4131-4136, 2004

31. Kao J, Milano MT, Javaheri A, Garofalo MC, Chmura SJ, Weichselbaum RR and Kron SJ: gamma-H2AX as a therapeutic target for improving the efficacy of radiation therapy. Curr Cancer Drug Targets 6: 197-205, 2006. 